\title{
Table of treaties
}

\section{EUROPEAN UNION TREATIES}

Treaty of Rome, Establishing the European Economic Community (adopted 25 March 1957, entered into force 1 January 1958) 298 UNTS 11 (EEC).... 23-29, 30,

Treaty of Maastricht (Treaty on the European Union) [1992] OJ C191/24 ............23-29, 37, 82, $83,85,86,137,150,199,321,485$,

Treaty of Nice, Amending the 486, 487

Treaty on European Union, the Treaties Establishing the European Communities and Certain Related Acts [2001] C80/01 ................23, 31, 32, 433

Protocol (No 2) on the Application of the Principles of Subsidiarity and Proportionality [2010] OJ C83/206 392,393

Consolidated version of the Treaty on European Union
[2012] OJ C326/01...... 13, 82, 320, 401,456

Consolidated version of the

Treaty on the Functioning of

the European Union [2012]

OJ C326/01 ....... 19, 21, 27, 28, 29, $30,32,34,37,38,48,50,62,68$, $69,70,76,81,95,96,137,142$, 146, 150, 151, 174, 199, 201, 206, 223, 227, 269, 270, 273, 274, 275, $276,277,278,279,283,287,291$, 292, 293, 300, 302, 306, 309, 316, $331,332,335,337,338,343,352$, $354,355,356,357,358,360,366$, $370,374,375,381,382,387,392$, $394,395,422,423,424,425,433$, 434, 457, 462, 468, 479, 481, 482, $486,489,490$

Charter of Fundamental Rights

of the European Union

[2012] OJ C326/391. 20,29 , 77, 78, 79, 81, 83, 87-94, 100, 101, $102,103,107,108,236,238,335$, $342,343,344,382,387,460,461$, $484,486,488-9,493$

\section{OTHER INTERNATIONAL TREATIES}

Charter of the United Nations (signed 26 June 1945, entered into force 24 October 1945) 1 UNTS XVI. 85,91

Constitution of the World Health Organization (adopted 22 July 1946, entered into force 7 April 1948) 14 UNTS 158 .405

General Agreement on Tariffs and Trade (adopted 30 October 1947, entered into force provisionally 1 January 1948)
55 UNTS 194 (GATT)...........429, 457, 464

Universal Declaration of Human

Rights (adopted 10 December

1948) UNGA Res 217 A(III)

(UDHR)..... $82,88,90,240$

Convention for the Protection of Human Rights and Fundamental Freedoms (European Convention on Human Rights, as amended) (signed 4 November 
1950 , entered into force 3

September 1953) CETS 5 77 , 85, 89, 91-3, 339, 461, 482, 493

Convention concerning Equal Remuneration for Men and Women Workers for Work of Equal Value (adopted 29 June 1951, entered into force 23 May 1953) (C 100) (Equal Remuneration Convention) ...... 94

The European Social Charter (adopted 18 October 1961, entered into force 26 February 1965) CETS 35. 85 90,93

Yaoundé I Convention between EAMA (Associated African and Malgache Countries) and EEC (adopted 20 July 1963, entered into force 1 June 1964); Yaoundé II Convention between EAMA and EEC (1969) 463

Lomé Convention I (adopted 28 February 1975, entered into force 1 April 1976), II (1979), III (1984) and IV (1990).... 463

International Covenant on Civil and Political Rights (adopted 16 December 1966, entered into force 23 March 1976) 999 UNTS 171 (ICCPR) .....88, 89

International Covenant on

Economic, Social and Cultural Rights (adopted 16 December 1966, entered into force 3 January 1976) 993 UNTS 3 . 90

European Convention on Products Liability in Regard to Personal Injury and Death (adopted 27 January 1977) CETS 91 172,173

European Convention for the Prevention of Torture and Inhuman or Degrading Treatment or Punishment (adopted 26 November 1987, entered into force 1 February 1989) CETS 126. 93
Convention on Biological

Diversity (adopted 5 June

1992, entered into force 29

December 1993) 1760 UNTS 79

Marrakesh Agreement

Establishing the World Trade

Organisation (adopted 15

April 1994, entered into force

1 January 1995) 1867 UNTS

154 (WTO Agreement) . .429

Agreement on Technical Barriers

to Trade (adopted 15 April

1994, entered into force 1

January 1995) 1868 UNTS

120 (TBT)

General Agreement on Trade in

Services (adopted 15 April

1994, entered into force 1

January 1995) 1869 UNTS

183 (GATS) .............433, 439, 440,

$442-4,457$

Agreement on Trade-Related

Aspects of Intellectual

Property Rights (adopted 15

April 1994, entered into force

1 January 1995) 1869 UNTS

299 (TRIPS) ..... 433, 457, 464, 465

Agreement on the Application of

Sanitary and Phytosanitary

Measures (adopted 15 April

1994, entered into force 1

January 1995) 1867 UNTS

493 (SPS)

European Social Charter

(Revised) (adopted 3 May

1996, entered into force 1 July

1999) CETS 163. 82,94

Convention for the protection

of Human Rights and

Dignity of the Human

Being with regard to the

Application of Biology

and Medicine: Convention

on Human Rights and

Biomedicine (adopted 4 April

1997, entered into force 1

December 1999) CETS 164

(Oviedo Convention) ..........88, 89, $91,93,236,238,455$ 
Cotonou Agreement (signed 23 June 2000, entered into force 1 April 2003) 463

Agreement establishing an association between the European Community and its Member States, of the one part, and the Republic of Chile, of the other part [2002] OJ L352/3 466

Council of Europe Protocol on Transplantation of Organs and Tissues of Human Origin (adopted 24 January 2002, entered into force 1 May 2006) CETS 186. 237,455

WHO Framework Convention on Tobacco Control (adopted 21 May 2003, entered into force 27 February 2005) 2302 UNTS $166 \ldots \ldots . .353,358,359,455$

Convention on the Rights of Persons with Disabilities UNGA Res 61/106 (13 December 2006) UN Doc A/ RES/61/106 460

Economic Partnership Agreement between the CARIFORUM States, of the one part, and the European Community and its Member States, of the other part [2008] OJ L289/I/3 ...................... 437, 466-7

Council of Europe Convention on the counterfeiting of medical products and similar crimes involving threats to public health (adopted 28 October 2011, entered into force 1 January 2016) CETS 211 (Medicrime Convention). .253

Free trade Agreement between the European Union and its Member States, of the one part, and the Republic of Korea, of the other part [2011] OJ L127/1

Political Declaration of the High-level Meeting of the General Assembly on the Prevention and Control of Non-communicable Diseases, UNGA 66th Session (16 September 2011) UN Doc A/66/L.1 370,371

Council of Europe Convention against Trafficking in Human Organs (adopted 25 March 2015) CETS 216. 455 